University of Nebraska - Lincoln

DigitalCommons@University of Nebraska - Lincoln

\title{
Influence of Corn Residue Harvest Management on Grain, Stover, and Energy Yields
}

Keri B. Cantrell

USDA-ARS, kbcantre@ncsu.edu

Jeffrey M. Novak

USDA-ARS, jeff.novak@ars.usda.gov

James R. Frederick

Clemson University, jfrdrck@clemson.edu

Douglas Karlen

USDA-ARS, doug.karlen@ars.usda.gov

Donald W. Watts

USDA-ARS, Don.Watts@ars.usda.gov

Follow this and additional works at: https://digitalcommons.unl.edu/usdaarsfacpub

Cantrell, Keri B.; Novak, Jeffrey M.; Frederick, James R.; Karlen, Douglas; and Watts, Donald W., "Influence of Corn Residue Harvest Management on Grain, Stover, and Energy Yields" (2014). Publications from USDA-ARS / UNL Faculty. 1642.

https://digitalcommons.unl.edu/usdaarsfacpub/1642

This Article is brought to you for free and open access by the U.S. Department of Agriculture: Agricultural Research Service, Lincoln, Nebraska at DigitalCommons@University of Nebraska - Lincoln. It has been accepted for inclusion in Publications from USDA-ARS / UNL Faculty by an authorized administrator of DigitalCommons@University of Nebraska - Lincoln. 


\title{
Influence of Corn Residue Harvest Management on Grain, Stover, and Energy Yields
}

\author{
Keri B. Cantrell • Jeffrey M. Novak • James R. Frederick • \\ Douglas L. Karlen • Donald W. Watts
}

Published online: 7 March 2014

(C) Springer Science+Business Media New York (outside the USA) 2014

This document is a U.S. government work and

is not subject to copyright in the United States.

\begin{abstract}
Economic, environmental, and energy independence issues are contributing to rising fossil fuel prices, petroleum supply concerns, and a growing interest in biomass feedstocks as renewable energy sources. Potential feedstocks include perennial grasses, timber, and annual grain crops with our focus being on corn (Zea mays L.) stover. A plot-scale study evaluating stover removal was initiated in 2008 on a South Carolina Coastal Plain Coxville/Rains-GoldsboroLynchburg soil association site. In addition to grain and stover yields, carbon balance, greenhouse gas (GHG) emissions and soil quality impact reported elsewhere in this issue, variation in gross energy distribution within various plant fractions whole plant, below ear shank (bottom), above ear shank (top), cob, as well as leaves and stems of the bottom and top portions $\left(n_{\text {(part, year) }}=20\right)$ was measured with an isoperibol calorimeter. Stalks from above the ear shank were the most energy dense, averaging $18.8 \mathrm{MJ} / \mathrm{kg} \mathrm{db}$, and when combined with other plant parts from above the ear shank, the entire top half was more energy dense than the bottom half -18.4 versus $18.2 \mathrm{MJ} / \mathrm{kg} \mathrm{db}$. Gross energy content of the whole plant, including the cob, averaged $18.28 \pm 0.76 \mathrm{MJ} / \mathrm{kg} \mathrm{db}$. Over the 4 years, partial to total removal (i.e., $25 \%$ to $100 \%$ ) of aboveground plant biomass could supply between 30 and $168 \mathrm{GJ} / \mathrm{ha}$ depending upon annual rainfall. At $168 \mathrm{GJ} / \mathrm{ha}$, the quantity of corn stover biomass (whole plant) available in a $3,254-\mathrm{km}^{2}$
\end{abstract}

K. B. Cantrell $\cdot$ J. M. Novak $(\bowtie) \cdot$ D. W. Watts

Coastal Plains Soil, Water, and Plant Research Center, USDA-ARS, 2611 West Lucas Street, Florence, SC 29501, USA

e-mail: jeff.novak@ars.usda.gov

J. R. Frederick

Pee Dee Research and Education Center, Clemson University, 2200

Pocket Road, Florence, SC 29501, USA

D. L. Karlen

National Laboratory for Agriculture and the Environment,

USDA-ARS, 2110 University Boulevard, Ames, IA 50011, USA area (32 km radius) around the study site could potentially support a 500-MW power plant.

Keywords Higher heating value $\cdot$ Residue removal $\cdot$ Crop management - Zea mays · Renewable Energy Assessment Project (REAP) · Bioenergy · Combustion

$\begin{array}{ll}\text { Abbreviations } \\ \text { B } & \text { Bottom (below ear) stover portion } \\ \text { BL } & \text { Bottom leaves portion } \\ \text { BS } & \text { Bottom stalk portion } \\ \text { HHV } & \text { Higher heating value } \\ \text { T } & \text { Top (above ear) stover portion } \\ \text { TL } & \text { Top leaves portion } \\ \text { TS } & \text { Top stalk portion } \\ \text { WP } & \text { Whole stover plant (excluding grain) }\end{array}$

\section{Introduction}

As demand for renewable bioenergy feedstock is growing and developing worldwide, prominent crops include: miscanthus (Miscanthus sinensis); switchgrass (Panicum virgatum); and sugarcane (Saccharum officinarum L.) bagasse - as well as corn (Zea mays L.) stover. This demand has also increased concerns regarding the sustainable use of current land and water resources; in addition to increased competition for those resources to provide both food and fuel [1]. Replenishing and preserving soil organic carbon is necessary to sustain crop productivity and soil structure; and returning crop residues, like corn stover, is an acknowledged management strategy [2]. However, uncertainty remains as to the amount of corn stover that must be returned to prevent subsequent decreases in both soil health and crop productivity. A number of studies, with a focus primarily within the U.S. Corn Belt, have examined the 
influence of corn stover removal on soil quality parameters [3-5]; additional studies are reported within this special issue. Emerging studies are addressing the mineral recycling and downstream ethanol impact by varied stover removal $[6,7]$. In the study of Johnson et al. [6], nutrient recycling was greatest for the stover's lower portion (below ear); likewise, retaining this portion on the field would lead to decreased nutrient replacement costs. In Mourtzinis et al. [7], the above ear portion of stover along with the cob was found to have the greatest holocellulose content. Greater holocellulose contents were desirable because they contributed to greater theoretical ethanol production. Furthermore, caution was emphasized when considering the lack of short term impact of stover removal on theoretical ethanol production. Despite the lifecycle thinking of these emerging studies, research is sparse regarding the impact of harvest strategies on stover quality especially when targeted for bioenergy generation purposes.

Corn stover is regarded as the dominant potential residue within the U.S. with corn stover biomass estimates ranging from 170 to 256 million dry tons [8]. The availability and abundance are just some of the characteristics of an ideal energy feedstock [9]. Other material properties are of interest when converting corn stover primarily into electrical and heat energy: moisture content, ash content, and the energy content (or higher heating value [HHV]) [9]. The extrinsic moisture content of crop residues is of primary concern as this is influenced by weather conditions during harvest. It may also be the easiest to control as many drying technologies exist. The ash content of the biomass also has extrinsic and intrinsic forms: the extrinsic ash content is influenced by the harvesting technique when the collected biomass is contaminated with soil; the intrinsic form would be that native to the plant tissue. Reported ash content of corn stover varies from $3.7 \%$ [10] to as high $11.23 \%$ [11]; the higher values are commonly associated with samples collected after processing with field harvesting equipment (e.g., from baled material). The ash represents the portion of the biomass that will remain after combustion. The magnitude of the ash content influences with available energy of the biomass: the larger the ash content of the biomass feedstock, the lower the energy content (energy per mass basis). The gross energy content or HHV associated with biomass represents the maximum amount of recoverable energy. It is the total energy content after biomass is burned that includes the latent heat of the water vapor product. Biomass products are desired with a larger HHV; however, most plant species generate HHV in the range of $17-$ $21 \mathrm{MJ} \mathrm{kg}^{-1}$ [9]. When biomass is combusted, the chemical energy is converted into heat, mechanical power, or electrical energy. Conversion and recovery of plant/residue biomass energy is within the range of $20-40 \%$ [12]. With this low conversion, the area of harvestable biomass increases 3-fold to support a unit of power. With this large jump in required land, stover residue management may be a way to hinder or enhance stover energy quality and mass quantity. Therefore, understanding how corn residue harvest management influences grain, stover and energy yields is an important component of establishing a sustainable bioenergy system.

Establishing a sustainable bioenergy system utilizing corn stover requires a multi-faceted approach. To meet this need a consortium of USDA-ARS researchers with university partners and engineers from the Idaho National Laboratory developed a multi-location, trans-disciplinary partnership to quantify and model the sustainability of corn stover harvest [13, 14]. The results of this study are presented within this special issue, including plant characteristics such as ash content and lignocellulosic content [7]. The specific objective presented here were (1) to quantify the gross energy distribution in various corn stover fractions when harvested for bioenergy production and (2) to determine the impact of annual residue removal on these properties in subsequent years. Utilizing existing continuous corn plots established in South Carolina on a Coastal Plains toposequential soil association that has an inherently low organic matter content and exhibits low nutrient retention.

\section{Materials and Methods}

\section{Site Description and Grain Harvest}

A field study was initiated in the spring of 2008 at the Pee Dee Research and Education Center $\left(-79^{\circ} \mathrm{W}\right.$ [longitude], $34^{\circ} \mathrm{N}$ [latitude]) located near Florence, South Carolina. The experimental site was the same each year, with the same stover removal treatments applied to an individual plot for each of the 5 years. Twenty research plots were established with an area allowing for planting $12(0.76 \mathrm{~m})$ rows of corn by $15 \mathrm{~m}$ long $\left(138 \mathrm{~m}^{2}\right)$. Toposequential soils consisting of the Goldsboro-Lynchburg-Coxville/Rains association were mapped along the plot transect. These are typical soil series within the Coastal Plains region used for row-crop production. Along the plot transect, there is a $0-1 \%$ slope that contributes to the various soil drainage classes (Table 1). The site has a long history (30 years) of row-crop production with the previous crop planted (2007) being soybean [Glycine $\max (\mathrm{L}$. Merr.]. Rainfall data, collected at daily intervals, was obtained from an on-site weather station.

Corn ('DeKalb hybrid DK69-71') was planted without any preplant tillage in mid-April of each year using a 6-row John Deere MaxEmerge XP no-till planter equipped with Kelly Manufacturing Company (KMC) in-row subsoiler shanks mounted in front of the planting coulters to fracture soil hardpan layers. The subsoil shanks preceded by straightedge coulters and followed by waffle coulters were set to a depth of $41 \mathrm{~cm}$ and spaced $76 \mathrm{~cm}$ apart. Corn seed was planted to achieve a plant population of 54,300 plants ha ${ }^{-1}$. 
Table 1 Soil series, USDA taxonomic classification and topsoil soil organic carbon (SOC) and pH properties for the Coastal Plains soils at the Pee Dee Research and Education Center field site

\begin{tabular}{lllr}
\hline Soil Series & Drainage class & Taxonomy & $\mathrm{SOC}\left(\mathrm{g} \mathrm{kg}^{-1}\right)$ \\
\hline Goldsboro & Moderately well drained & Fine loamy, siliceous, subactive Aquic Paleudult & 9.38 \\
Lynchburg & Somewhat poorly drained & Fine loamy, siliceous, semiactive Thermic Aeric Paleaquult & 8.01 \\
Coxville & Poorly drained & Fine, kaolinitic, thermic Typic Paleaquult & 6.0 \\
Rains & Poorly drained & Fine loamy, siliceous, semiactive Typic Paleaquult & 5.7 \\
\hline
\end{tabular}

Phosphorus and $\mathrm{K}$ fertilizer was broadcast applied each year at rates based upon soil test results from Clemson University Agricultural Service Laboratory (http://www.clemson.edu/ public/regulatory/ag_svc_lab/soil_testing). Eight soil samples were collected in March from each plot to a depth of $15 \mathrm{~cm}$, bulked, subsampled, and air-dried for subsequent soil test analyses. Liquid $\mathrm{N}$ as urea ammonium nitrate was side-dressed applied $20 \mathrm{~cm}$ from the crop row at a rate of $45 \mathrm{~kg} \mathrm{~N} \mathrm{ha}^{-1}$ at planting and at $90 \mathrm{~kg} \mathrm{~N} \mathrm{ha}^{-1}$ at the $\mathrm{V} 6$ (sixth leaf) growth stage. Herbicides were applied every year at planting and at the V6 growth stage as recommended by the Clemson University Cooperative Extension Service (http:// www.clemson.edu/extension) for the types of weed species present. Irrigation water was applied each year in an amount of $2 \mathrm{~cm}$ per application when rainfall was less than $1.3 \mathrm{~cm}$ total for a 2-week period.

The experimental treatments consisted of five levels of corn residue removal $(0 \%, 25 \%, 50 \%, 75 \%$, and $100 \%)$ as measured at harvest maturity. Four replicates of different levels of residue removal were arranged in the field as a Randomized Complete Block Design. Each plot was harvested using a CASE 2366 combine equipped with a small grain header. The corn residues (leaves, stalk, and cob) from each plot were caught in a suspended canvas tarp attached to the back of the combine as they exited the machine. Residues from each plot were weighed, subsampled for moisture determination, and returned manually across the same plot at the rate specified for each treatment. Grain yield for each plot was measured using a grain wagon placed on truck scales. A subsample from each plot collected for moisture determination, but for comparative purposes, yields were computed on a dry basis (i.e., $\mathrm{kg}_{\mathrm{db}} \mathrm{ha}^{-1}$ ). The stover and grain yields from these measurements were referred to as "field-measured" and differed from the grab samples described below.

\section{Stover Sampling and Analyses}

Approximately 2 weeks prior to combine harvest, corn plant samples (pre-harvest samples) were collected from a total area of $4.52 \mathrm{~m}^{2}$ within each plot. The samples were processed by dividing them into the following eight plant parts: whole plant (WP); top ( $\mathrm{T}$ ) - representing biomass above the ear shank including the cob; bottom (B) - representing biomass below the ear shank; cobs only (Cob); top leaves (TL); top stalk (TS); bottom leaves (BL); and bottom stalk (BS). Grain was not included in any of these fractions. Whole plant biomass yields were collected from a 2- $\mathrm{m}^{2}$ area; $\mathrm{T}, \mathrm{B}$, and Cob biomass yields were determined from a separate $1.52 \mathrm{~m}^{2}$ sample area; and TL, TS, BL, BS, and Cob biomass yields were based on samples collected from a third $1-\mathrm{m}^{2}$ area. Various areas for these biomass estimates were chosen to meet the research needs of colleagues with the ARS-Florence and ARS-NLAE locations. All stover and cob biomass fractions were dried at $60{ }^{\circ} \mathrm{C}$ before weighing and calculating biomass yields in $\mathrm{kg}$ $\mathrm{ha}^{-1}$ at a water content of $0 \mathrm{~g} \mathrm{~kg}^{-1}$. A portion of the dried corn stover was ball milled and analyzed for total plant carbon (OC), total combustible nitrogen (TCN), and energy density or HHV. Both OC and TCN were measured using a LECO TruSpec CN analyzer (Leco Corp., St. Joseph, MI, USA); HHV of a sample was determined using a LECO AC500 Isoperibol Calorimeter (Leco Corp.) following ASTM D5865 [15]. Subsequent bioenergy yields removed (GJ $\mathrm{ha}^{-1}$ ) were calculated as the product of removal rate, energy density $\left(\mathrm{MJ} \mathrm{kg}^{-1}\right)$, and biomass yield.

In order to condense all the available results, averaged results across removal treatments are provided for years 2009 and 2012. The results in 2009 represent the first year response to the treatment; 2012 results represent the end of the current study. The full dataset can be found in the USDA ARS REAPnet database (http://nrrc.ars.usda.gov/slreap/\#/Home) [16].

\section{Statistics}

Data were analyzed by Proc GLMMIX (General Linear Mixed Model) with plot replications as the random effect using Version of 9.2 of Statistical Analysis System (SAS Institute Inc., Cary, NC, USA). Significant differences between plant parts and removal rates were based on an $F$-test $(P<0.10)$.

\section{Results and Discussion}

Collection year influenced every measured variable for every plant part; this was primarily due to differences in amount and 
timing of rainfall. Therefore, each variable was analyzed for statistical differences by year. Total rainfall from planting to harvest for 2009 through 2012, respectively, was 648, 668, 198, and $693 \mathrm{~mm}$; rainfall received prior to day 70 (when tasseling generally began) totaled $337,234,92$, and $318 \mathrm{~mm}$, respectively (Fig. 1). This difference in rainfall quantity and distribution caused notable changes in the stover biomass measured both in the field at harvest (Table 2) and in the pre-harvest samples (Table 3): when there was sufficient rain (i.e., 2009, 2010, and 2012), average field-measured stover biomass was $7,380 \pm 787 \mathrm{~kg} \mathrm{ha}^{-1}$. In 2011, even with $96 \mathrm{~mm}$ of supplemental irrigation to save the crop, field-measured stover production was only $4,796 \mathrm{~kg} \mathrm{ha}^{-1}$. Grain yields varied significantly across years leading to the harvest index ranging from $22.4 \%$ (2011) to $48.2 \%$ (2009) (Table 2). Maximum grain yield occurred in 2009 with 7,510 $\pm 869 \mathrm{~kg}_{\mathrm{db}} \mathrm{ha}^{-1}$; the lowest grain yield was measured in 2011 at $1,440 \pm 560 \mathrm{~kg}_{\mathrm{db}}$ $\mathrm{ha}^{-1} ; 2010$ and 2012 grain yields averaged $5,250 \pm 800 \mathrm{~kg}_{\mathrm{db}}$ $\mathrm{ha}^{-1}$.

No statistically significant effects were noted for the grain yields any year (Table 2). However, it is interesting to note that the $50 \%$ removal treatment had the lowest yield 3 of the 5 years, and in at least 2 years, the $100 \%$ removal had the greatest yield. These responses suggest yield response is not proportional related to removal rate. Indeed yield response to removal reflects interaction with other management practices, soil properties, microclimate, and environment $[17,18] \mathrm{We}$ observed that $\mathrm{p}$ values associated with removal treatment declined each year from 0.921 to 0.185 suggesting additional time is necessary to observe statistically significant influences of stover removal on grain yields. This longer amount of time needed is contrary to the stover removal impacts for an Ohio Rayne silt loam; in just two harvest cycles, $100 \%$ stover removal as compared to $0 \%$ removal was found to decrease subsequent grain yields by roughly $33 \%$ [19]. However, a

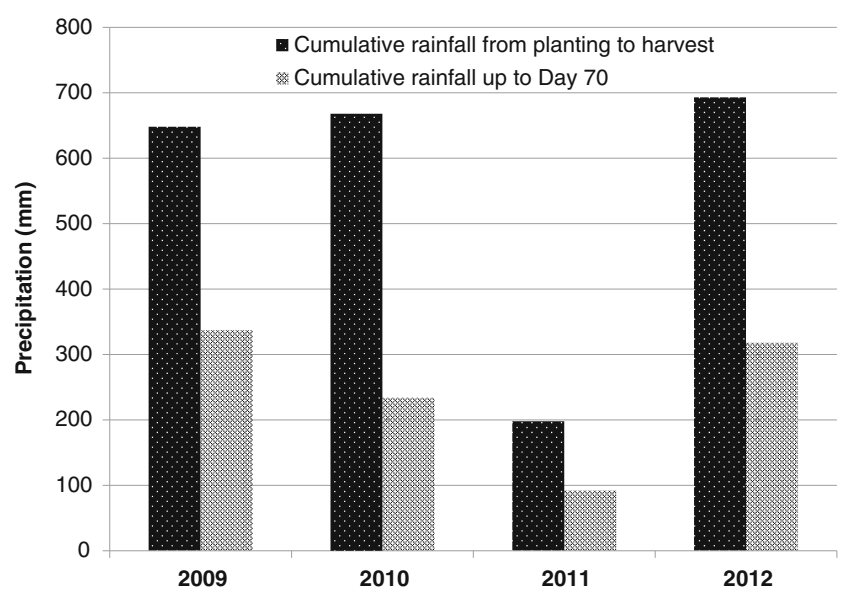

Fig. 1 Cumulative rainfall $(\mathrm{mm})$ from corn planting date to harvest date and for rainfall up to day 70 when tasseling usually begins lack of crop yield response to short-term stover harvest is consistent with other studies [20].

Stover removal had no significant effect on the HHV of any plant part (Table 3 ). There were significant year $\times$ removal interactions for all fractions - except for the whole plant fraction. A trend $(P=0.141)$ for removal effects on HHV were noted for 2009 within the bottom, bottom stalk, top leaves and top stalk fractions. Residue removals greater than $50 \%$ decreased HHV for the bottom and bottom stalks; bottom leaves remained relatively constant (data not shown). Both top leaves and top stalk fractions had HHVs that trended downward with increasing removal. As the experiment progressed, the general trend was for the HHV of all plant parts to remain the same or below 2009 values (Table 3; Fig. 2). This trend, however, could also have been caused by growing corn on the same site for 5 consecutive years. Continuous corn would not be a typical crop rotation for the southeastern Coastal Plains for many reasons including increased insect and pathogen pressures. Previous corn production research at this location showed a very significant decrease in yield when the corn was grown for 3 consecutive years despite the use of optimum row spacing, plant population, irrigation, and nutrient management practices [21].

Comparing plant parts, top stalks had the greatest $\mathrm{HHV}$ at $18.8 \mathrm{MJ} \mathrm{kg}^{-1}$. This was closely followed by $\mathrm{Cob}$ and top leaves fractions at 18.6 and $18.5 \mathrm{MJ} \mathrm{kg}^{-1}$, respectively. Bottom leaves (BL) had the lowest measured HHV of $17.8 \mathrm{MJ} \mathrm{kg}^{-1}$. With a strong interaction between plant part and year, 2011 samples were consistently greater than the others. For example, $2011 \mathrm{WP}$ HHV was $19.0 \mathrm{MJ} \mathrm{kg}^{-1}$, which was greater than those listed for WP in Table 3. This increase in HHV is likely due to drought-induced lignocellulosic changes in the plant reported by [7]. With adequate rainfall, the plant prioritizes nutrient and photosynthetic resources into grain production as demonstrated by harvest index values ranging from $41 \%$ to $48 \%$ (Table 2). For 2011, the harvest index dropped to $22.4 \%$; this suggested that the plant was simply unable to fill the grain without cannibalizing stalk carbohydrates. As a consequence of preserving the stalk integrity during drought conditions, the whole plant lignin content (as measured by wet chemistry techniques [22, 23]) was greatest for whole plant samples obtained in 2011 (86.7 $\mathrm{g} \mathrm{kg}^{-1}$ ); whole plant samples in 2010 and $2012 \mathrm{had}$ lignin concentrations of 35.7 and $51.2 \mathrm{~g} \mathrm{~kg}^{-1}$, respectively [7].

Over the course of this study, overall organic carbon in the stover did not vary more than $50 \mathrm{~g} \mathrm{~kg}^{-1}(5 \%)$ within the various plant parts. Total carbon was only affected by removal in the top stalk stover portion. TCN only was affected by stover removal within top fractions (T, TL, and TS). Interactive effects of year and removal were noted for bottom stalk. Since TCN concentrations were low numerically, small absolute changes in concentrations led to significant differences when comparing TCN values between years. 
Table 2 Field-measured grain and corn stover biomass yields and harvest index [grain/(grain + stover yield) $\times 100]$ (Mean and standard deviation [Std]) for each year and removal rate $(n=4)$

\begin{tabular}{|c|c|c|c|c|c|c|c|}
\hline \multirow[t]{3}{*}{ Harvest year } & \multirow[t]{3}{*}{ Stover removal rate $(\%)$} & \multirow{2}{*}{\multicolumn{2}{|c|}{$\frac{\text { Field measured grain yield }}{{\mathrm{kg} \text { biomass } \mathrm{ha}^{-1}, 0 \% \text { moisture }}}$}} & \multirow{2}{*}{\multicolumn{2}{|c|}{$\frac{\text { Field measured corn stover }}{\mathrm{a}}$}} & \multicolumn{2}{|c|}{ Harvest index (\%) } \\
\hline & & & & & & & \\
\hline & & Mean & Std & Mean & Std & Mean & Std \\
\hline \multirow[t]{5}{*}{2009} & 0 & 7,875 & 1,290 & 8,550 & 738 & 47.8 & 2.6 \\
\hline & 25 & 7,355 & 693 & 7,730 & 435 & 48.7 & 2.6 \\
\hline & 50 & 7,427 & 613 & 7,930 & 719 & 48.4 & 3.9 \\
\hline & 75 & 7,578 & 1090 & 7,760 & 661 & 49.3 & 1.9 \\
\hline & 100 & 7,332 & 892 & 8,300 & 688 & 46.9 & 5.0 \\
\hline \multirow[t]{5}{*}{2010} & 0 & 4,736 & 1,230 & 6,680 & 923 & 41.1 & 3.1 \\
\hline & 25 & 4,655 & 253 & 6,500 & 401 & 41.8 & 2.8 \\
\hline & 50 & 4,253 & 902 & 6,220 & 973 & 40.6 & 7.4 \\
\hline & 75 & 4,840 & 351 & 6,780 & 385 & 41.7 & 3.1 \\
\hline & 100 & 4,923 & 351 & 6,500 & 853 & 43.2 & 2.7 \\
\hline \multirow[t]{5}{*}{2011} & 0 & 1,473 & 304 & 4,590 & 392 & 24.2 & 3.4 \\
\hline & 25 & 1,565 & 631 & 4,960 & 821 & 23.3 & 4.7 \\
\hline & 50 & 1,070 & 640 & 4,790 & 608 & 17.3 & 8.0 \\
\hline & 75 & 1,532 & 712 & 4,710 & 724 & 24.2 & 10.4 \\
\hline & 100 & 1,543 & 589 & 4,940 & 816 & 23.2 & 6.2 \\
\hline \multirow[t]{5}{*}{2012} & 0 & 5,944 & 697 & 8,000 & 1,120 & 42.8 & 3.8 \\
\hline & 25 & 5,508 & 1,330 & 7,010 & 866 & 43.7 & 8.6 \\
\hline & 50 & 5,372 & 527 & 7,320 & 1,350 & 42.6 & 2.6 \\
\hline & 75 & 5,755 & 769 & 7,930 & 885 & 42.0 & 2.7 \\
\hline & 100 & 6,501 & 922 & 7,510 & 540 & 46.3 & 2.4 \\
\hline
\end{tabular}

${ }^{a}$ Field measured stover represented the material exiting the combine during harvest

Comparing 2009 to 2012, TCN changed within $55 \%$ for $\mathrm{Cob}$ and top leaves; however, the trends were opposing: over time, Cob TCN decreased and top leaves TCN increased. The TCN concentration in the WP increased from 2009 to 2012 by $66 \%$.

Overall, corn stover biomass yields (pre-harvest measurements) were impacted by removal rate. The whole plant $(P \leq 0.0688)$, bottom $(P \leq 0.0001)$, bottom stalk $(P \leq$ $0.0547)$ stover yields decreased with removal (Fig. 3). The bottom yield consistently declined with increasing stover removal rates. Whereas, top leaves biomass yields offered no clear response to removal treatments $(P \leq 0.0984): 25 \%$ stover removal had the lowest yield with the remaining four treatments having similar top leaf yields (Fig. 3). These decreases in stover biomass yields were less than those associated with a Rayne silt loam in Ohio with $100 \%$ stover removal decreasing the biomass yield after two harvest cycles by roughly $25 \%$ [16]. Further investigation of the ratio of each plant part to the WP revealed that stover removals greater than $50 \%$ decreased the $\mathrm{B} / \mathrm{WP}$ ratio (bottom to whole plant); conversely, T/WP ratio (top to whole plant) increased with removals approaching 75-100\%; Cob/WP ratio remained relatively steady. Thus, removal of the stover promotes the biomass accumulation in the top portion of the plant.

Since bioenergy yields ( $\mathrm{GJ} \mathrm{ha}^{-1}$ ) were a product of HHV $\left(\mathrm{MJ} \mathrm{kg}^{-1}\right)$ and the stover biomass yields $\left(\mathrm{kg} \mathrm{ha}^{-1}\right)$ (Table 3), stover removal management did affect bioenergy yields for bottom, bottom stalk, top leaves, as well as the whole plant; these energy yields trended downward with increased removal rates (Fig. 2). Persistent removal gradually decreased the total available stover energy after three additional cycles from 168 \pm 12 to $153 \pm 9 \mathrm{GJ} \mathrm{ha}^{-1}$. This decrease in stover energy yields was probably not due to growing continuous corn, however, since no removal $(0 \%)$ resulted in the greatest amount of potential bioenergy in the various plant fractions.

Inherent in the harvesting and removal process are different amounts of bioenergy being removed from the field. Greater stover removal results in greater bioenergy available for offfarm purposes. With increases in available energy per unit area, larger power plants can be supported (Fig. 4). Assuming $30 \%$ electrical conversion efficiency [12], $100 \%$ removal of the WP during productive years (e.g., 2009) could provide 
Table 3 Higher heating value, biomass and energy yield, plant $\mathrm{C}$ and $\mathrm{N}$ in various corn stover fractions collected approximately 2 weeks prior to field harvest

\begin{tabular}{|c|c|c|c|c|c|c|c|c|c|c|c|}
\hline \multirow[t]{3}{*}{ Part $^{\mathrm{a}}$} & \multirow[t]{3}{*}{ Year } & \multirow{2}{*}{\multicolumn{2}{|c|}{$\begin{array}{l}\text { Higher heating value } \\
\left(\mathrm{MJ} \mathrm{kg}_{\mathrm{db}}{ }^{-1}\right)\end{array}$}} & \multirow{2}{*}{\multicolumn{2}{|c|}{$\begin{array}{l}\text { Total dry residue }^{\mathrm{b}} \\
\left.\text { (kg biomass } \mathrm{ha}^{-1}, 0 \% \text { moisture }\right)\end{array}$}} & \multirow{2}{*}{\multicolumn{2}{|c|}{$\frac{\text { Plant bioenergy available }}{\left(\mathrm{GJ} \mathrm{ha}^{-1}, 0 \% \text { moisture }\right)}$}} & \multirow{2}{*}{\multicolumn{2}{|c|}{$\begin{array}{l}\text { Average plant organic carbon } \\
\left(\mathrm{g} \mathrm{kg}^{-1}\right)\end{array}$}} & \multirow{2}{*}{\multicolumn{2}{|c|}{$\begin{array}{l}\begin{array}{l}\text { Average plant } \\
\text { combustible nitrogen }\end{array} \\
\left(\mathrm{g} \mathrm{kg}^{-1}\right)\end{array}$}} \\
\hline & & & & & & & & & & & \\
\hline & & Mean & Std & Mean & Std & Mean & Std & Mean & Std & Mean & Std \\
\hline \multirow[t]{2}{*}{ B } & 2009 & 18.18 & 0.62 & 4678 & 449 & 85.48 & 9.21 & 465.9 & 1.9 & 5.1 & 0.9 \\
\hline & 2012 & 17.93 & 0.37 & 4334 & 475 & 77.72 & 8.76 & 469.5 & 3.2 & 6.4 & 1.3 \\
\hline \multirow[t]{2}{*}{ BL } & 2009 & 17.43 & 0.52 & 1409 & 222 & 24.55 & 3.73 & 458.5 & 15.7 & 10.1 & 2.5 \\
\hline & 2012 & 17.78 & 0.34 & 1321 & 268 & 23.51 & 4.89 & 454.3 & 3.9 & 10.0 & 1.8 \\
\hline \multirow[t]{2}{*}{ BS } & 2009 & 18.38 & 0.90 & 2763 & 496 & 50.75 & 9.24 & 470.5 & 5.0 & 4.0 & 0.9 \\
\hline & 2012 & 17.55 & 0.40 & 2644 & 469 & 46.38 & 8.18 & 475.5 & 5.8 & 4.8 & 2.0 \\
\hline \multirow[t]{2}{*}{$\mathrm{Cob}$} & 2009 & 18.30 & 0.79 & 1685 & 212 & 30.82 & 3.94 & 482.6 & 10.4 & 7.0 & 3.9 \\
\hline & 2012 & 18.25 & 0.28 & 1383 & 147 & 25.23 & 2.75 & 484.8 & 4.2 & 4.5 & 0.9 \\
\hline \multirow[t]{2}{*}{$\mathrm{T}$} & 2009 & 18.57 & 0.38 & 5238 & 608 & 97.15 & 10.74 & 467.0 & 2.9 & 4.9 & 1.0 \\
\hline & 2012 & 18.06 & 0.24 & 5665 & 316 & 102.33 & 6.19 & 476.9 & 3.0 & 6.8 & 1.0 \\
\hline \multirow[t]{2}{*}{ TL } & 2009 & 18.95 & 0.70 & 2487 & 386 & 47.20 & 7.95 & 465.6 & 2.1 & 4.3 & 1.0 \\
\hline & 2012 & 17.63 & 0.14 & 3163 & 652 & 55.76 & 11.6 & 469.4 & 3.4 & 8.4 & 1.4 \\
\hline \multirow[t]{2}{*}{ TS } & 2009 & 19.31 & 0.64 & 809 & 136 & 15.61 & 2.63 & 478.2 & 3.6 & 4.6 & 0.9 \\
\hline & 2012 & 17.79 & 0.30 & 1006 & 352 & 17.88 & 6.23 & 471.8 & 3.3 & 5.6 & 1.3 \\
\hline \multirow[t]{2}{*}{ WP } & 2009 & 18.54 & 0.73 & 9079 & 620 & 168.24 & 11.81 & 467.8 & 3.0 & 4.1 & 0.9 \\
\hline & 2012 & 17.26 & 0.43 & 8855 & 528 & 152.78 & 8.65 & 468.4 & 4.7 & 6.8 & 1.4 \\
\hline
\end{tabular}

Values are means and standard deviation (Std) calculated across stover removal treatments for 2009 (initial) and 2012 (final) study years $(n=4)$

sufficient biomass to maintain a 500-MW electrical generation system when the harvest area has a radial distance of $32 \mathrm{~km}$ (i.e., $3,254 \mathrm{~km}^{2}$ harvest area). To obtain this power from lower biomass yielding years (e.g., 2011), the radius would need to expand to $40 \mathrm{~km}\left(5,085 \mathrm{~km}^{2}\right.$ area). The shift in land area rewuirement clearly demonstrates the need to plan facilities to respond to the potential of fluctuating feedstock availability.
Fig. 2 Removal rate effects on total whole plant stover fraction bioenergy yield potential (lines) and whole plant stover fraction higher heating value ( $H H V ;$ bars $)$

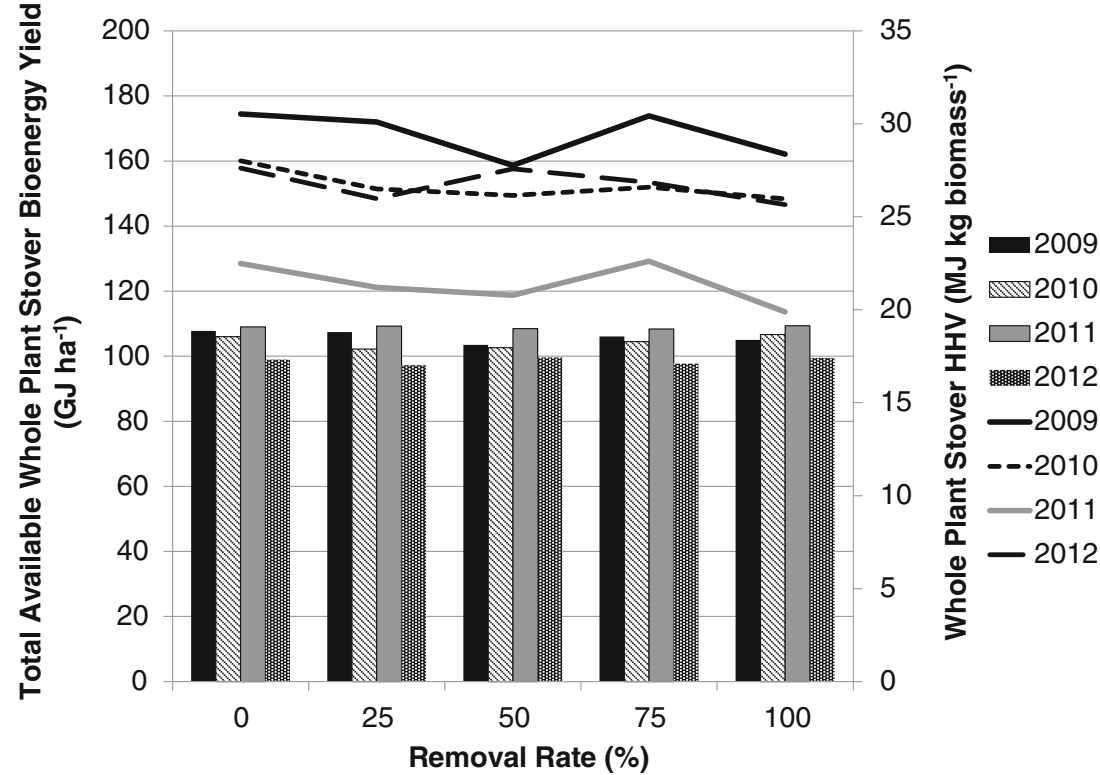




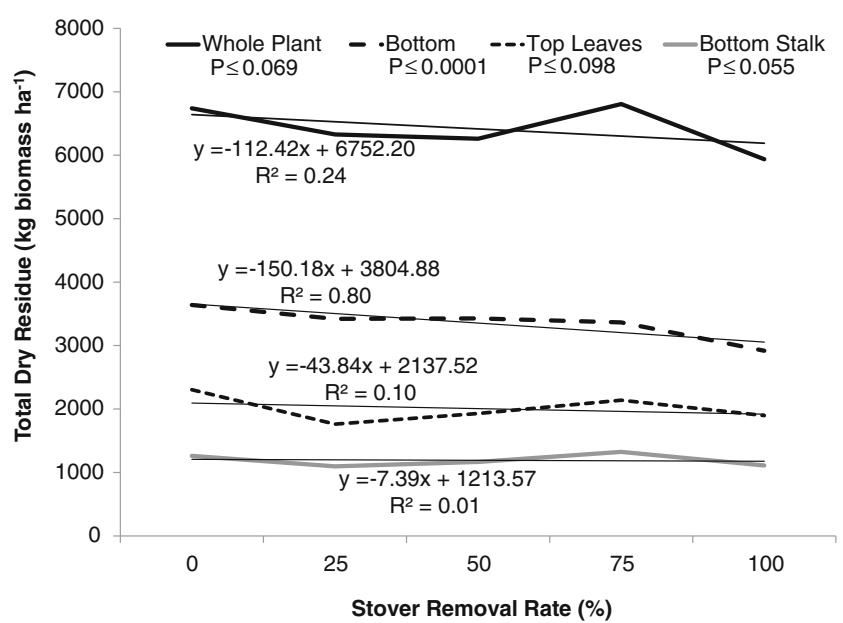

Fig. 32011 total dry residue among four stover fractions collected at preharvest affected by stover residue management; $P$ values presented are associated with removal rate effects over the life of the study

\section{Summary and Conclusions}

This study shows that for continuous corn grown on Coastal Plain soils increased stover removal can have a negative impact on the quantity and quality (high energy content); thus, this impacts the required harvestable area to support local power plants. Both stover biomass yields and stover bioenergy yields were negatively affected when stover was removed over four harvest cycles. The HHV trended downward with increasing removal, particularly for the top (above ear) portions of the plant. With continued residue management, the HHV gradually decreased. While no stover removal effects on grain yield were considered statistically significant, the trend was that increased removal decreased grain yield; it also suggested that a longer time period is necessary to view a difference, possibly just one more harvest cycle.

This study quantified potential energy availability from the stover and provided information needed to plan for various

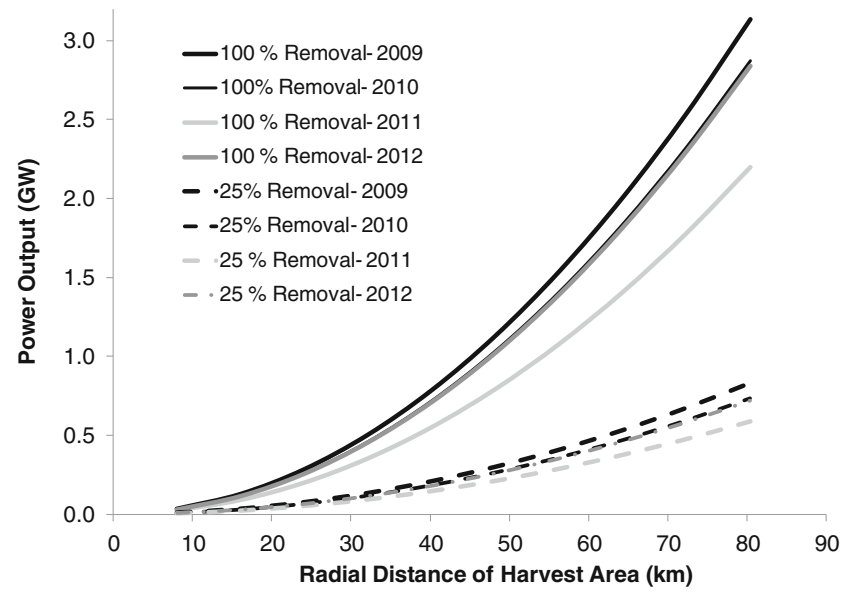

Fig. 4 Relative power plant size* supported by combustion of removed whole plant corn stover within a defined radius based on two potential stover removal rates. ${ }^{*}$ Calculations assume $30 \%$ conversion efficiency types of bioenergy conversion facilities. Obviously, corn stover will probably not be the feedstock of choice for the southeastern Coastal Plains; nonetheless, this information provides HHV values for multiple stover fractions. Furthermore, it provided a clear example of how year-toyear variations in crop yield impact the land area footprint to support bioenergy production. Thus, this study augments the overall effort to establishing a sustainable bioenergy system.

Acknowledgments The authors thank the many hands involved with field and sample collection, sample preparation, and sample analyses: Chuck Parker, Karen Barefoot, Sheneeka Sansbury, Ashley Kelley, Elizabeth Ford, Brittney Wallace, Cierra Buckman, Joe Millen, and Jerry Martin II. The authors thank Dr. Jane Johnson and the journal reviewers for their input into the revisions. The authors would like to acknowledge the following for funding: USDA-Agricultural Research Service as part of the USDA-ARS-REAP project. Additional funding sources were with the North Central Regional SunGrant Center at South Dakota State University through a grant provided by the USDOE - Office of Biomass Programs under award number DE-FC36-05GO85041.

Mention of trade names or commercial products in this publication is solely for the purpose of providing specific information and does not imply recommendation or endorsement by the U.S. Department of Agriculture. USDA is an equal opportunity provider and employer.

\section{References}

1. Pimentel D, Marklein A, Toth MA, Karpoff MN, Paul GS, McCormack R, Kyriazis J, Krueger T (2009) Food versus biofuels: environmental and economic costs. Hum Ecol 37(1):1-12. doi:10. 1007/s10745-009-9215-8

2. Wilhelm WW, Johnson JMF, Karlen DL, Lightle DT (2007) Corn stover to sustain soil organic carbon further constrains biomass supply. Agron J 99:1665-1667

3. Johnson J, Acosta-Martinez V, Cambardella C, Barbour N (2013) Crop and soil responses to using corn stover as a bioenergy feedstock: observations from the Northern US Corn Belt. Agriculture 3(1):72-89. doi:10.3390/agriculture3010072

4. Karlen DL, Varvel GE, Johnson JMF, Baker JM, Osborne SL, Novak JM, Adler PR, Roth GW, Birrell SJ (2011) Monitoring soil quality to assess the sustainability of harvesting corn stover. Agron J 103(1): 288. doi:10.2134/agronj2010.0160s

5. Blanco-Canqui H, Lal R (2009) Corn stover removal for expanded uses reduces soil fertility and structural stability. Soil Sci Soc Am J 73(2):418. doi:10.2136/sssaj2008.0141

6. Johnson JMF, Wilhelm WW, Karlen DL, Archer DW, Wienhold B, Lightle DT, Laird D, Baker J, Ochsner TE, Novak JM, Halvorson AD, Arriaga F, Barbour N (2010) Nutrient removal as a function of corn stover cutting height and cob harvest. Bioenerg Res 3(4):342352. doi:10.1007/s12155-010-9093-3

7. Mourtzinis S, Cantrell KB, Arriaga F, Novak JM, Frederick JR, Karlen DL (2014) Distribution of structural carbohydrates in corn plants as influenced by corn residue management. Bioenerg Res. doi: 10.1007/s12155-014-9429-5

8. U.S. Department of Energy (2011) U.S. billion-ton update: biomass supply for a bioenergy and bioproducts industry. R.D. Perlack and B.J. Stokes (Leads), ORNL/TM-2011/224. Oak Ridge National Laboratory, Oak Ridge, $227 \mathrm{pp}$

9. McKendry P (2002) Energy production from biomass: Part 1. Overview of biomass. Bioresour Technol 83:37-46 
10. Demirbas A (1997) Calculation of higher heating values of biomass fuels. Fuel 76(5):431-434

11. Kaliyan N, Morey RV (2009) Densification characteristics of corn stover and switchgrass. Trans ASABE 52(3):907-920

12. McKendry P (2002) Energy production from biomass: Part 2. Conversion technologies. Bioresour Technol 83:47-5413

13. Karlen DL (2010) Corn stover feedstock trials to support predictive modeling. GCB Bioenergy 2:235-247

14. Karlen DL, Johnson JMF (2014) Crop residue considerations for sustainable bioenergy feedstock supplies. Bionergy Res (in press)

15. STM (2006) Petroleum products, lubricants, and fossil fuels: gaseous fuels, coal, and coke. ASTM International, W. Conshohocken

16. Del Grosso SJ, White JW, Wilson G, Vandenberg B, Karlen DL, Follett RF, Johnson JMF, Franzluebbers AJ, Archer DW, Gollany HT, Liebig MA, Ascough J, Reyes-Fox M, Pellack L, Starr J, Barbour N, Polumsky RW, Gutwein M, James D (2013) Introducing the GRACEnet/REAP data contribution, discovery, and retrieval system. J Environ Qual 42(4):1274. doi:10.2134/jeq2013.03.0097

17. Wilhelm WW, Johnson JMF, Hatfield JL, Voorhees WB, Linden DR (2004) Crop and soil productivity response to corn residue removal: a literature review. Agron J 96(1):1-17
18. Johnson JMF, Papiernik SK, Mikha MM, Spokas KA, Tomer MD, Weyers SL (2010) Soil processes and residue harvest management. In: Lal R, Stewart BA (eds) Carbon management fuels and soil quality. Taylor and Francis, New York, pp 1-44

19. Blanco-Canqui H, Lal R (2007) Soil and crop response to harvesting corn residues for biofuel production. Geoderma $141: 355-362$

20. Karlen DL, Birrell SJ, Johnson JMF, Osborne SL, Schumacher TE, Varvel GE, Ferguson RB, Novak JM, Frederick JR, Baker JM, Lamb JA, Adler PR, Roth GW, Nafziger ED (2014). Multi-location corn stover harvest effects on crop yields and nutrient removal. Bioenergy Res 1-12. doi:10.1007/s12155-014-9419-7

21. Karlen DL, Camp CR (1985) Row spacing, plant population, and water management effects on corn in the Atlantic Coastal Plain. Agron J 77:393-398

22. Van Soest PJ (1963) Use of detergents in the analysis of fibrous feeds: II. A rapid method for the determination of fiber and lignin. J Off Assoc. Anal Chem 46:828

23. Van Soest PJ, Wine RH (1967) Use of detergents in the analysis of fibrous feeds: IV. Determinations of plant cell wall constituents. J Off Assoc Anal Chem 50:50 